\title{
PRINSIP TANGGUNG JAWAB PENGANGKUT DAN ASURANSI GANTI RUGI TERHADAP KORBAN KECELAKAAN PENUMPANG UMUM DI JALAN RAYA
}

\author{
Mig Irianto Legowo*
}

\begin{abstract}
Responsibility of Carriers for accident victims on the highway and how the process of providing compensation by PT Persero Raharja insurance services, as well as problems that arise in the maintenance of obtaining compensation insurance (compensation). The type of research used is normative juridical research type. The analytical method used is a qualitative normative data analysis method. The results of the study can be concluded: 1) Responsibility for the error of the Carrier is carried out as a family. While compensation for PT. (Pesero) Jasa Raharja's Loss Insurance is determined by the way of handling, namely by the way the victim or heir comes to Jasa Raharja's office to request the K1 form (for accidents hit by a motor vehicle) or K2 (for public passenger accidents), which is filled in correctly and fulfills conditions: information on road traffic accidents by the police, doctor's statement, and heir's statement if the victim dies and if the conditions are met correctly then the implementation of compensation will be able to run smoothly, provided it is guaranteed by Law No. 34 of 1964 jo. PP No. 18 of 1965. 2). The obstacles that exist in the implementation of Law No. 34 of 1964 concerning: Road Traffic Accident Funds are derived from victims or heirs of the victims in the form of community reluctance to take care of claims for compensation, this is due to the fear of dealing with authorities or state officials
\end{abstract}

\section{Keywords : Principles of Carrier Responsibility, Compensation Insurance, Victims of Accident General Passenger}

\section{PENDAHULUAN}

Kegiatan pengangkutan merupakan salah satu bentuk jenis kegiatan transportasi memegang peranan yang sangat penting untuk memenuhi kebutuhan hidup manusia sehari-hari, karena kegiatan pengangkutan membantu memperlancar kegiatan pengiriman arus barang dan jasa dari satu tempat ke tempat lain yang lebih mempunyai manfaat dan nilai guna. Menurut Rustian Kamaludin, menyatakan bahwa pada dasarnya pengakutan atau transportasi atau perpindahan penumpang

\footnotetext{
* Mig Irianto Legowo adalah Pengajar di Fakultas Hukum Universitas 17 Agustus 1945 Semarang dapat dihubungi melalui email : migirianto55 @gmail.com
}

atau barang dengan transportasi adalah dengan maksud untuk dapat mencapai tempat tujuan dan menciptakan atau menaikkan utilitas atau kegunaan dari barang yang diangkut, yaitu utilitas karena tempat dan utilitas karena waktu. ${ }^{1}$ Sedangkan menurut Sri Rejeki Hartono, pegangkutan dilakukan karena nilai barang akan lebih tinggi di tempat tujuan dari pada di tempat asalnya, karena itu dikatakan pengangkutan memberi nilai kepada barang yang diangkut dan nilai ini lebih besar dari pada biaya-biaya yang dikeluarkan, nilai yang diberikan adalah berupa nilai tempat (place utility) dan nilai waktu (time utility).

\footnotetext{
1 Rustian Kamaluddin, Ekonomi Transportasi, Karakteristik, Teori Dan Kebijakan, Ghalia Indonesia, Jakarta, 2003, hal.14.
} 
Nilai tempat (pleace utility) mengandung pengertian bahwa dengan adanya pengangkutan berarti terjadi perpindahan barang dari suatu tempat, di mana barang tadi dirasakan kurang berguna atau bermanfaat di tempat asal, akan tetapi setelah adanya pengangkutan nilai barang tersebut bertambah, bermanfaat dan memiliki nilai guna bagi manusia, oleh karena itu apabila dilihat dari kegunaan dan manfaatnya bagi manusia, maka barang tadi sudah bertambah nilainya karena adanya pengangkutan. Sedangkan Nilai kegunaan waktu (time utility), dengan adanya pengangkutan berarti bahwa dapat dimungkinkan terjadinya suatu perpindah an barang dari suatu tempat ke tempat lainnya di mana barang tersebut lebih diperlukan tepat pada waktunya. ${ }^{2}$

Sejalan dengan kemajuan jaman dan teknologi dewasa ini, khususnya teknologi kendaraan bermotor telah mengalami kemajuan yang pesat dengan produk-produk baru kendaraan bermotor yang terus menerus bertambah, maka bertambah pula kendaraan bermotor khususnya angkutan umum, dengan berkembangnya jumlah perusahaan angkutan umum yang beroperasi di indonesia dewasa ini sungguh sangat pesat untuk mengangkut penumpang dan barang, dilihat dari begitu semakin padatnya arus lalu lintas di jalan raya dan mungkin akan bertambah lagi di masa yang akan datang, karena tidak ada pembatasan berapa perusahaan angkutan umum yang boleh beroperasi.

Akibat berlakunya otonomi daerah, ada juga perusahaan-perusahaan angkutan umum yang dimiliki oleh pemerintah daerah, dan milik swasta, dan koperasi angkutan umum, sehingga, akan dapat menimbulkan berbagai dampak antara lain sering terjadi kemacetan lalu lintas di jalan

2 Sri Rejeki Hartono, Pengangkutan dan Hukum pengangkutan Darat, Seksi Hukum Dagang, Fakultas Hukum Universitas Diponegoro, Semarang, 1982, hal.8. raya dan kecelakaan.

Apabila kecelakaan lalu lintas di jalan raya itu terjadi pada kendaraan angkutan penumpang umum akan mengakibatkan kerugian antara lain korban luka-luka, sakit, cidera/cacat tetap, bahkan korban jiwa manusia dan harta benda, hal ini siapakah yang bertanggung jawab dalam penanganan terhadap korban kecelakaan penumpang umum di jalan raya? Menurut sumber berita Kompasiana.com, tanggal 9 mei 2014, perkiraan angka korban lalulintas di Indonesia mencapai angka 30.000 jiwa/ tahun, sementara "Korban meninggal pada tahun 2016 mencapai 25.859 orang dan di tahun 2017 ada 24.213 orang atau turun 6 persen," ujar Wakapolda Metro Jaya Brigjen Pol Purwadi Arianto di Mapolda Metro Jaya, Jakarta, Kamis (1/3/2018). Walaupun mengalami turun sekitar 6 persen, maka bisa menjadi indikasi bahwa Indonesia berada di titik paling meng hawatirkan. Pada dasarnya pengemudi kendaraan bermotor yang menyebabkan kecelakaan adalah pihak yang bertanggung jawab dan diwajibkan untuk memberi ganti kerugian kepada pemilik kendaraan dan korban kecelakaan yang diakibatkan oleh kelalaianya. Akan tetapi kalau terjadi kecelakaan di jalan raya pada kendaraan angkutan umum untuk penumpang dan atau barang, lalu siapakah yang bertanggung jawab untuk memberikan ganti kerugian/santunan terhadap korban kecelakaan terhadap penumpang umum di jalan raya ?, sesuai dengan ketentuan undang-undang setiap perusahaan angkutan umum diwajibkan untuk mengasuransikan tanggung jawabnya dalam Undang-undang RI nomor 22 tahun 2009 tentang lalu-lintas dan angkutan jalan raya pada pasal 188 dinyatakan bahwa "Perusahaan angkutan umum wajib menganti kerugian yang diderita oleh penumpang atau pengirim barang karena lalai dalan melaksanakan pelayanan angkutan" Sesuai dengan ketentuan Undang-undang tersebut perusahaan 
angkutan umum diwajibkan untuk mengasuransikan tanggung jawabnya (legal liability insurance). Sebenarnya perusahaan pengangkutan umum yang mengasuransikan tanggung jawabnya itu adalah suatu keharusan dari ketentuan, akan tetapi terlepas dari diasuransikan atau tidak diasuransikan, perusahaan angkutan umum tersebut harus memberikan kompensasi kepada para korban penumpang umum, sehingga orang sering mencampur adukan antara kompensasi atau santunan dari perusahaan angkutan umum dengan asuransi yang diberikan oleh PT. (Persero) Asuransi Kerugian Jasa Raharja ini adalah merupakan suatu kewajiban perusahaan asuransi jasa raharja untuk membayar santunan adalah berdasarkan Undangundang nomor 33 dan 34 tahun 1964 yaitu semua penumpang angkutan umum yang mengalami kecelakaan berhak mendapat santunan dari jasa raharja, hal ini berbeda dengan kompensasi dari perusahaan angkutan umum, akibatnya sering dalam praktek angkutan penumpang umum sehari-hari pihak perusahaan pengangkutan umum tidak pernah ada yang memberikan santunan kepada pihak penumpang yang mengalami korban kerugian karena kecelakaan di jalan raya. Suatu contoh peristiwa tabrakan maut yang melibatkan Bus Sumber Kencono dengan sebuah mini Bus Travel akibat tabrakan yang terjadi di Mojokerto Jawa Timur, sedikitnya 21 orang tewas termasuk pengemudi kendaraan ini. Perumusan masalah penelitian ini adalah:

1. Bagaimana tanggung jawab peng angkut terhadap korban kecelakaan penumpang umum di jalan raya?

2. Bagaimana proses pemberian ganti kerugian (santunan) oleh PT. (Persero) Asuransi Kerugian Jasa Raharja terhadap korban kecelakaan penumpang umum di jalan raya?

\section{Metode Penelitian}

Metode Penelitian ini menggunakan tipe yuridis normative yaitu metode penelitian yang melihat gejala-gejala hukum bertumpu pada hukum atau peraturan yang berlaku untuk selanjutnya akan ditinjau dan dibahas secara lebih mendalam. Metode analisa yang digunakan, adalah metode analisa data yang bersifat normatif kualitatif, yang artinya suatu metode pembahasan atau analisa terhadap faktor-faktor atau data hasil penelitian dengan bahan kumpulan peraturan per-undang-undangan, konsep, doktrin, sistem, teori hukum tanpa mempergunakan perhitungan statistik. Sumber Data yang digunakan adalah Sumber data primer dan Sumber data sekunder.

\section{PEMBAHASAN}

\section{Tanggung jawab Pengangkut Terhadap Korban Kecelakaan Penumpang Umum.}

Masalah pokok yang menjadi problem dalam hukum pengangkutan baik nasional maupun internasional adalah masalah tanggung jawab pengangkut bila terjadi kerugian yang diderita oleh pengguna jasa angkutan (penumpang, pemilik bagasi, pengirim/penerima barang), disamping itu juga kemungkinan terjadi kerugian pada pihak ketiga (thirdparty liability) di darat yaitu jiwa dan harta benda. Sampai di mana sistem tanggung jawab pengangkut yang dapat dijadikan perlindungan hukum terhadap penumpang angkutan umum, dalam teori hukum pengangkutan hal ini tergantung pada prinsip prinsip tanggung jawab pengangkut yang dianut dalam undangundang pengangkutan yang mengatur. Dalam ilmu hukum, khususnya hukum pengangkutan secara umum, menurut Abdul Kadir mohammad dalam Hukum Pengangkutan Darat laut dan Udara didapat ada 3 (tiga) prinsip tangung jawab pengangkut dalam hukum pengangkutan 
yaitu : ${ }^{3}$

a. Prinsip tanggung jawab berdasarkan karena adanya unsur kesalahan (faut liability, liability based on fault).

b. Prinsip Tanggung jawab berdasarkan praduga (Presumption of liability) dan

c. Prinsip Tanggung jawab mutlak (nofault liability, absolute, atau strict liability).

Adapun caranya membedakan dari ketiga prinsip tanggung jawab pengangkut tersebut ada pada masalah pembuktiannya yaitu pada ada atau tidaknya kewajiban untuk membuktikan, dan terhadap siapa beban bukti itu dibebankan dalam proses acara pembuktian dipengadilan.

\section{a. Prinsip Tanggung Jawab Berdasarkan Adanya Unsur Kesalahan}

Berdasarkan prinsip tanggung jawab adanya unsur kesalahan ini memberikan pelajaran bahwa tanggung jawab setiap orang terletak pada ada atau tidaknya kesalahan yang diperbuat. Tidak ada satupun seseorang yang bertanggung jawab tanpa adanya suatu kesalahan, maka dalam hal ini sama yaitu jika seorang penggugat ingin menuntut tanggung jawab terhadap tergugat oleh karena kerugian yang diderita korban dari perbuatannya, maka pihak penggugat harus dapat membuktikan adanya kesalahan pihak tergugat, selain itu pihak penggugat harus juga membuktikan bahwa tergugat menderita kerugian tersebut sebagai akibat dari perbuatan penggugat.

Terkait dalam masalah pengangkut an antara pelaku usaha dalam hal ini pengusaha angkutan umum dengan pihak konsumen yaitu penumpang angkutan umum yang mengalami korban kerugian akibat kecelakaan, maka pihak penumpang yang akan menuntut sebagai konsumenlah

3 Abdul kadir Muhammad, Hukum Pengangkutan Darat, Laut, Dan Udara, PT. Cirtra Aditya, Bandung, 1994, hal 27 yang harus membuktikan adanya unsur kesalahan yang diperbuat oleh pihak pengusaha angkutan umum, bagi pihak penumpang untuk membuktikan adanya unsur kesalahan terhadap pengusaha angkutan bukanlah persoalan yang mudah tapi merupakan masalah sulit untuk dapat membuktikan karena pihak penumpang orang yang awam, apalagi posisinya sebagai korban kecelakaan dan masih banyak lagi masalah baik yang berkaitan dengan ekonomi dan tehnologi, jadi dalam hal ini beban pembuktian ada pada pihak yang dirugikan, bukan pada pihak pengangkut atau pengusaha angkutan. Prinsip ini adalah yang umum dipakai dan berlaku seperti yang diatur dalam pasal 1365 KUHPdt tentang perbuatan melawan hukum.

\section{b. Prinsip Tanggung Jawab Berdasarkan Praduga}

Menurut prinsip tanggung jawab berdasarkan praduga (presumption of liability) Pihak pengusaha angkutan dianggap selalu yang bertanggung jawab pada setiap kerugian yang timbul dari pengangkutan yang diselenggarakannya, tetapi jika pengangkut dapat membuktikan bawa ia tidak bersalah, maka ia dibebaskan dari kewajiban membayar ganti kerugian,. yang dimaksud "tidak bersalah" adalah tidak melakukan kelalaian, dan telah mengambil tindakan yang perlu untuk menghindari kerugian, atau peristiwa yang menimbulkan kerugian itu tidak mungkin dihindari, beban pembuktian ini ada pada pihak pengangkut bukan pada pihak yang dirugikan Pihak yang dirugikan cukup menunjukan adanya kerugian yang diderita dalam pengangkutan yang diselenggarakan oleh pihak pengangkut.

Pada dasarnya prinsip tanggung jawab berdasarkan praduga adalah prinsip tanggung jawab berdasarkan unsur kesalahan (liability based on fault), tetapi di sini terjadi pembalikan beban pembuktian 
(omkering van de bewijslaast,shifting of the burden of proof) kepada pihak tergugat, sehingga apabila penggugat (korban) yang akan mengajukan tuntutan untuk memperoleh santunan tidak perlu membuktikan adanya kesalahan pihak tergugat atau penggugat, tetapi tergugat cukup menunjukan bahwa kecelakaan atau terjadinya kerugian yang diderita pada dirinya terjadi selama mereka berada dalam alat angkut, kemudian apabila pengangkut berupaya akan membebaskan diri dari tanggung jawab untuk membayar ganti kerugian atau santunan, maka pihak pengangkut harus dapat membuktikan bahwa dirinya tidak bersalah.

Adanya sistim pembalikan beban pembuktian ini, maka berdampak pada adanya ketentuan pembatasan tanggung jawab pengangkut untuk memberikan santunan dibatasi sampai limit tertentu. Dalam perjanjian pengangkutan antara perusahaan angkutan dengan pihak penumpang / pengirim barang diperboleh kan memakai adanya prinsip tanggung jawab karena praduga, biasanya dirumus kan dalam perjanjian pengangkutan yang menyatakan "kecuali jika perusahaan angkutan dapat membuktikan bahwa kerugian bukan karena kesalahannya." Jadi prinsip tanggung jawab karena praduga ini merupakan pengecualian, artinya pada prinsipnya pihak pengangkut bertanggung jawab atas setiap kerugian yang timbul dalam pengangkutan, tetapi jika pihak pengangkut dapat membuktikan bahwa dia tidak bersalah/lalai, maka pihak peng angkut dapat dibebaskan dari tanggung jawab untuk mengganti kerugian pada pihak penumpang.

\section{c. Prinsip Tanggung Jawab Mutlak (no-fault liability, absolute, atau strict liability)}

Dalam prinsip tanggung jawab mutlak initergugat maupun penggugat selalu wajib bertanggung jawab tanpa dan tidak melihat ada atau tidaknya kesalahan yang diperbuat oleh pihak pengangkut atau pihak penumpang umum, jadi artinya tidak melihat pihak siapa yang melakukan kesalahan, dengan kata lain, unsur kesalahan tidak dipermasalahkan dalam prinsip tanggung jawab mutlak. Dalam teori ilmu hukum prinsip tanggung jawab ini biasanya dikenal dengan istilah strict liability dan absolute liability, dari kedua istilah tersebut pendapat dari beberapa ahli hukum ada yang membedakan dan ada pula yang mempersamakan. Menurut Mieke Komar Kantaatmadja, dalam Tanggung Jawab Dalam Pencemaran Udara

Mengatakan mempersamakan strict liability dengan absolute liability, berdasarkan prinsip ini, pihak tergugat harus membayar seluruh kerugian yang disebabkan oleh tindakannya, terlepas dari bersalah tidaknya tergugat, sedangkan dalam strict liability selalu disertai dengan penentuan jumlah ganti rugi celling, selain itu dalam prinsip ini tidak dipermasalahkan adanya unsur kesalahan, kesengajaan, atau kelalaian, asal ada cukup pembuktian tentang terjadinya kerugian akibat perbuatan tergugat. ${ }^{4}$ Sedangkan menurut E. Saefullah Wiradipradja, dalam Tanggung Jawab Pengangkut Dalam Hukum Udara Internasional dan Nasional, dengan mengutip dari Winfielt, Friedman, dan Mircea Mateescomatte, mengatakan membedakan antara strict liability dengan absolute liability dengan memperhatikan ada atau tidaknya kemungkinan untuk membebaskan diri dari tanggung jawab, dalam srict liability dalam hal tertentu dimungkinkan adanya pembebasan tanggung jawab, sedangkan di dalam absolute liability hal tersebut tidak dimungkinkan. ${ }^{5}$

4 Mieke Komar Kantaatmadja, Ganti Rugi Internasional Pencemaran Minyak di Laut, Alumni, , Bandung, 1981, hal 74-76

5 E. Saefullah Wiradipradja, Tanggung-jawab Pengangkut Dalam Hukum Udara Internasional dan Nasional, Liberty, Yogyakarta, 1989, hal. 3637 
Jadi menurut prinsip tanggung jawab mutlak ini pihak pengangkut harus selalu bertanggung jawab untuk membayar ganti kerugian terhadap setiap kerugian yang timbul dari pengangkutan yang diselenggarakannya pada pihak pe numpang, tanpa adanya keharusan untuk membuktikan ada atau tidaknya kesalahan pihak pengangkut maupun pihak penumpang.

Kesimpulannya pihak pengangkut tidak mungkin dapat membebaskan diri dari tanggung jawabnya untuk membayar ganti kerugian dengan alasan apapun yang menimbulkan kerugian itu.

Jadi pada prinsip ini tidak mengenal beban pembuktian tentang ada atau tidaknya kesalahan pihak pengangkut atau pihak penumpang.

Dalam praktek hukum pengangkut an penerapan prinsip tanggung jawab mutlak sudah cukup memberikan perlindungan hukum bagi penumpang sebagai konsumen pengguna jasa angkutan maupun bagi pengusaha angkutan sendiri, karena sebagai imbalannya diterapkannya prinsip tanggung jawab mutlak kepada pengusaha angkutan diberikan batas jumlah tanggung jawab dalam mengganti kerugian terhadap penumpang yang karena terjadi kecelakaan yang tidak dapat dilampaui dalam keadaan apapun juga.

Serta pengusaha angkutan dapat dibebaskan dari tanggung jawab untuk mengganti kerugian bila terbukti bahwa kecelakaan / kerugian terjadi disebabkan karena keadaan kesehatan pihak penumpang sendiri atau karena keikutsertaan korban sendiri dalam menyebabkan terjadinya kecelakaan/ kerugian (contributorynegligence).

Selain itu bagi korban atau ahli warisnya akan lebih terjamin untuk memperoleh santunan dari perusahaan angkutan penumpang atas korban kerugian karena kecelakaan yang dideritanya, serta proses pembayarannya pun relative lebih pendek. ${ }^{6}$ Apabila prinsip-prinsip tanggung jawab pengangkut ini dihubungkan dengan undang-undang yang mengatur ketiga jenis pengangkutan, maka undang-undang pengakutan udara menganut prinsip tanggung jawab mutlak, sedangkan undang-undang yang mengatur pengangkut an darat, dan pengangkutan laut di Indonesia, ternyata menganut prinsip tanggung jawab berdasarkan praduga, karena hal ini terbukti antara lain sebagai contoh pengangkutan darat sesuai ketentuan dalam pasal-pasalnya sebagai berikut antara lain : yaitu dalam pasal 188 Undang-undang Republik Indonesia nomor 22 Tahun 2009 tentang Lalu-lintas dan Angkutan Jalan yang berbunyi, "Perusahaan angkutan umum wajib mengganti kerugian yang diderita oleh penumpang atau pengirim barang karena lalai dalam melaksanakan pelayanan angkutan."

Dalam pasal 192 (ayat 1) menyatakan : "Perusahaan angkutan umum bertanggung jawab atas kerugian yang diderita oleh penumpang yang meninggal dunia atau luka-luka akibat penyelenggara an angkutan, kecuali disebabkan oleh suatu kejadian yang tidak dapat dicegah atau dihindari atau karena kesalahan penumpang", dalam (ayat 2) nya menyatakan : kerugian sebagaimana dimaksud pada ayat 1 dihitung berdasarkan kerugian yang nyata-nyata dialami atau bagian biaya pelayanan, selanjutnya dalam (ayat 3) menyatakan : "Tanggung jawab sebagaimana dimaksud pada ayat 1 dimulai sejak penumpang diangkut dan berakhir di tempat tujuan yang disepakati", serta dalam pasal 235 (ayat1) menyatakan : "jika korban meninggal dunia akibat kecelakaan lalulintas sebagaimana dimaksud dalam pasal

6 E. Saefullah Wiradipradja, Penerapan Prinsip Tanggungjawab Mutlak (Strict Liability) Dalam Peraturan Perundang-undangan Khususnya di Bidang Angkutan Udara, Pidato Pengukuhan Guru Besar Tetap Ilmu Hukum, Fakultas Hukum Universitas Padjajaran, Bandung, Bandung, 1991, Hal. 15 
229 ayat (1) huruf e, pengemudi, pemilik, dan/atau perusahaan angkutan umum wajib memberikan bantuan kepada ahli waris korban berupa biaya pengobatan dan/atau biaya pemakaman dengan tidak menggugurkan tuntutan perkara pidana", dan dalam ayat 2 berbunyi : "jika terjadi cidera terhadap badan atau kesehatan korban akibat kecelakaan lalu-lintas sebagaimana dimaksud dalam pasal 229 ayat 1 huruf $\mathrm{b}$ dan huruf $\mathrm{c}$, pengemudi, pemilik,dan/atau perusahaan angkutan umum wajib memberikan bantuan kepada korban berupa biaya pengobatan dengan tidak menggugurkan tuntutan perkara pidana".

\section{Proses pemberian ganti Kerugian (Santunan) Oleh PT. (Persero) Asuransi Kerugian Jasa Raharja Terhadap Korban Kecelakaan Penumpang Umum Di Jalan Raya}

Dalam praktek pengangkutan sehari hari terhadap penumpang umum di jalan raya di Indonesia jika terjadi peristiwa kecelakaan yang menyebabkan kerugian pada pihak korban antara lain luka-luka, sakit, cidera/cacat tetap, bahkan korban jiwa manusia, dan harta benda, maka sesuai dengan ketentuan dalam perundangundangan pasal 188 Undang-undang RI nomor 22 tahun 2009 tentang lalu-lintas dan angkutan jalan yang berbunyi : Perusahaan angkutan umum wajib mengganti kerugian yang diderita oleh penumpang atau pengirim barang karena lalai dalam melaksanakan pelayanan angkutan, selanjutnya dalam pasal 189 undangundang tersebut, menyatakan bahwa : perusahaan angkutan umum wajib mengasuransikan tanggung jawabnya sebagaimana dalam pasal 188, sehingga kewajiban untuk memberikan ganti kerugian terhadap korban kecelakaan penumpang umum dapat dialihkan kepada pihak lain yaitu perusahaan asuransi, selanjutnya premi asuransi ini akan ditutup oleh pihak pengusaha angkutan umum melalui tiket atau karcis penumpang umum, dalam hal ini pemerintah menunjuk PT. (Persero) Asuransi Kerugian Jasa Raharja sebagai pihak penanggung dan perusahaan angkutan umum sebagai pihak tertanggung. Jadi yang memperoleh jaminan ganti rugi dari PT (Persero) Asuransi Kerugian Jasa Raharja bukan hanya pemilik kendaraan tetapi pemakai kendaraan pada saat terjadi kecelakaan juga mendapat ganti rugi baik itu berupa biaya perawatan maupun santunan. Untuk itu pemerintah menunjuk PT (Persero) Asuransi Kerugian Jasa Raharja untuk melaksanakan penyeleng garaan dana pertanggungan wajib kecelakaan lalu lintas jalan.

Untuk melaksanakan program tersebut dan memberikan landasan hukum yang kuat bagi terlaksananya program pemberian jaminan sosial yang dimaksudkan dan agar dapat berjalan dengan daya evektifitas yang lebih mantap, maka pemerintah mengeluarkan peraturan perundang-undangan yang dikenal dengan nama : Undang-undang Nomor 33 tahun 1964 tentang "Dana Pertanggungan Wajib Kecelakaan Penumpang" Jo Peraturan Pemerintah, Nomor 17 Tahun 1965 sebagai peraturan pelaksanaanya, dan Undangundang Nomor 34 Tahun 1964 Tentang "Dana Kecelakaan Lalu-lintas Jalan" Jo. Peraturan Pemerintah nomor 18 Tahun 1965 sebagai peraturan pelaksanaanya. Perlu diketahui bahwa setiap korban kecelakaan lalu-lintas, baik Darat, Laut, dan Udara telah diasuransikan oleh jasa raharja, sehingga bila terjadi kecelakaan, korban atau ahli waris dapat mengklaim asuransi kecelakaan yang menimpa dirinya atau keluarganya kepada pihak Jasa Raharja untuk mendapat santunan. ${ }^{7}$

Apabila tempat/daerah di mana kecelakaan terjadi lain dengan daerah wilayah kerja PT (Persero) Asuransi

7 mhtmi:File://D: \Dok.Untag $\backslash$ Cara Klaim Asuransi Kecelakaan Jasa Raharja, mht! http://Pemuda Indonesia Baru, 9-8-2011. 
Kerugian Jasa Raharja maka permintaan hak santunan asuransi dapat diajukan pada kantor cabang terdekat. Peranan PT (Persero) Asuransi Kerugian Jasa Raharja sangatlah besar bagi pengguna jalan raya karena korban kecelakaan akan mendapat kan rugi dari perusahaan asuransi, baik itu biaya perawatan rumah sakit, ataupun apabila korban menjadi cacat tetap dan korban meninggal dunia akan mendapatkan santunan dari PT (Persero) Asuransi Kerugian Jasa Raharja. Akan tetapi masih ada kendala lain yaitu kurangnya kesadaran atau pengetahuan dari korban atau ahli warisnya bahwa mereka mempunyai hak santunan ganti rugi dari PT. (Persero) Asuransi Kerugian Jasa Raharja, sehingga mereka tidak segera mengurusnya dan juga kadang-kadang korban dalam mengurus santunan ini minta tolong kepada orang lain, hal ini mengakibatkan pengajuan tuntutan santunan tidak bisa lancar karena yang dimintai pertolongan itu mempunyai pamrih tertentu, hal inilah menjadi pekerjaan rumah bagi PT (Persero) Asuransi Kerugian Jasa Raharja dalam memasyarakatkan asuransi itu sendiri.

Perlu dicatat bahwa sehubungan dengan masalah asuransi ini orang sering salah persepsi atau pengertian, baik di kalangan pemerintah sendiri maupun di kalangan umum, Sebenarnya tujuan pemerintah mengadakan asuransi kecelakaan lalu lintas jalan raya adalah untuk meringankan orang yang mendapat kecelakaan sebagai akibat dari kecelakaan lalu lintas jalan, serta untuk memberikan kepastian hukum dalam hal ini kepastian untuk memperoleh santunan ganti kerugian. Tujuan ini dapat tercapai jika semua pihak diikutsertakan oleh pemerintah untuk melaksanakannya. Masing-masing memenuhi kewajibannya termasuk dalam hal kewajiban membayar sumbangan wajib yang jumlahnya ditentukan oleh menteri keuangan pada tiap pemilik kendaraan bermotor, namun disisi lain dalam praktek sehari-hari kenyataannya pengusaha angkutan umum justru tidak ikut bertanggung jawab, bahkan justru melepaskan tanggung-jawabnya sama sekali pada korban kecelakaan umum, dengan perkataan lain tidak mempunyai rasa perikemanusian dalam meringankan beban kepada para korban kecelakaan penumpang umum, berarti tujuan Pemerintah bahwa pengusaha angkutan umum wajib untuk ikut meringankan beban kepada para korban kecelakaan penumpang umum tidak tercapai, sebab tanggung jawab untuk memberikan santunan tidak dijalankan sesuai dengan amanat undangundang yang dicanangkan oleh pemerintah. Selain itu juga setiap pemilk kendaraan sepeda motor roda dua diwajibkan untuk memiliki kartu dana atau sertifikat sumbangan wajib dana kecelakaan lalu lintas jalan raya (SWDKLL). Kartu dana atau sertifikat ini merupakan tanda bukti pelunasan sumbangan peralihan resiko tanggung jawab dari pemilik kendaraan sepeda motor roda dua kepada PT. (Perseoro) Asuransi Kerugian Jasa Raharja terhadap korban kecelakaan lalu lintas jalan yang ditimbulkan oleh kendaraan bermotor yang telah melunasi sumbangan wajib, karena nanti jika sewaktu-waktu telah terjadi kecelakaan terhadap dirinya yang dimana kecelakaan berhadapan dengan kendaraan bermotor penumpang umum, maka akan juga mendapatkan asuransi ganti kerugian dari PT. (Persero) Asuransi kerugian Jasa Raharja.

Dasar Hukum Asuransi Kerugian Jasa Raharja sampai saat ini UU. Nomor 33 Tahun 1964 tentang "Dana Pertanggungan wajib Kecelakaan Penumpang Umum" dan No. 34 Tahun 1964 tentang "Dana Kecelakaan Lalu-lintas Jalan" masih tetap dikelola oleh PT. (Persero) Asuransi Kerugian Jasa Raharja. Pendirian PT. (Persero) Asuransi Kerugian Jasa Raharja dilakukan dihadapan notaris, dengan akta pendirian No. 49 Tahun 1981 tanggal 28 Pebruari 1981. 
Dengan keputusan menteri keuangan RI Nomor Kep/759 MK.IV/II/ 1970 Perusahaan Asuransi Kerugian Jasa Raharja ditetapkan dengan kedudukan sebagai Perum Asuransi Kerugian Jasa Raharja, maka melalui Peraturan Pemerintah.Nomor 39 tahun 1980 bentuk usahanya dirubah menjadi Persero dengan nama PT. (Persero) Asuransi Kerugian Jasa Raharja. Jadi bertitik tolak dari UU. No. 34 tahun 1964 pasal 5 (1) Jo. PP No. 18 Tahun 1965. Menurut Pasal 3 ayat 1 Undangundang Nomor 33 Tahun 1964 Pengertian Penumpang adalah : Tiap Penumpang yang sah dari kendaraan bermotor umum, kereta api, pesawat terbang perusahaan penerbangan nasional dan kapal perusahaan perkapalan/pelayaran nasional, wajib membayar iuran melalui pengusaha/pemilik yang bersangkutan untuk menutup akibat keuangan disebabkan kecelakaan penumpang dalam perjalanan.

Berdasarkan Undang-undang nomor 33 tahun 1964 ,jo.PP. nomor 17 tahun 1965, menentukan bahwa : Korban yang berhak mendapatkan atas santunan yaitu : ${ }^{8}$

a. Setiap penumpang sah alat angkutan penumpang umum yang mengalami kecelakaan diri, yang diakibatkan oleh penggunaan alat angkutan umum, selama penumpang yang bersangkutan berada dalam angkutan tersebut yaitu saat naik, dari tempat pemberangkatan sampai turun di tempat tujuan.

b. Jaminan ganda, kendaraan bermotor umum (bis) berada dalam kapal ferry, apabila kapal ferry dimaksud mengalami kecelakaan, kepada penumpang bis yang menjadi korban diberikan jaminan ganda.

c. Penumpang mobil plat hitam, bagi penumpang mobil plat hitam yang mendapat izin resmi sebagai alat

8 http://www.jasaraharja.co.id/layanan/lingkupjaminan/UU-no-34-tahun-1964-jo-PP-no-18tahun-1965 angkutan penumpang umum, seperti antara lain : mobil pariwisata, mobil sewa, dan lain-lain.terjamin oleh UU no.33 tahun 1964, jo PP no. 17/1965.

d. Korban yang mayatnya tidak diketemukan, penyelesaian santunan bagi korban yang mayatnya tidak diketumukan dan atau hilang didasarkan kepada putusan Pengadilan Negeri.

Adapun besarnya ganti kerugian atau santunan yang diberikan oleh PT. (Pesero) Asuransi Kerugian Jasa Raharja kepada korban yang mengalami kecelakaan penumpang umum terdapat dalam Undangundang nomor 33 tahun 1964, ditetapkan berdasarkan peraturan menteri keuangan RI nomor : KEP. 15/PMK/010/2017, tanggal 13 februari 2017, tentang besarnya santunan dan iuran : wajib dana pertang gungan wajib kecelakaan penumpang alat angkutan umum di darat, sungai/danau, ferry/penyeberangan, laut dan udara adalah sebagai berikut:

a. Dalam hal korban meninggal Rp. 50.000.000,00 (untuk angkutan umum melalui darat yaitu : Bus Umum, Kereta Api, dan kapal laut), sedangkan untuk angkutan umum melalui pesawat udara dalam hal korban meninggal dunia sebesar Rp. $50.000 .000,00$

b. Biaya perawatan dan pengobatan dokter dengan jumlah sebanyak Rp. 20.000.000,00 (untuk angkutan umum melalui darat yaitu : Bus Umum, Kereta Api, dan Kapal Laut), Sedangkan untuk angkutan umum melalui pesawat udara dalam hal korban meninggal dunia sebesar Rp. 50.000.000,-

c. Santunan cacat tetap untuk korban yang menderita cacat tetap menurut ketetapan dokter yang merawat sesuai prosentase yang ditentukan dalam peraturan dan di dalam undangundang No. 33 tahun 1964 setinggitingginya Rp. 50.000.000,00,- (untuk 
angkutan umum melalui darat yaitu : Bus Umum, Kereta Api, dan Kapal Laut), sedangkan untuk angkutan umum melalui pesawat udara dalam hal korban meninggal dunia sebesar Rp. 50.000.000,00,-

d. Biaya penguburan bagi korban yang tidak mempunyai ahli waris sebagaimana dimaksud dalam PP. No. 17 tahun 1965 sebesar Rp. 4.000.000,00,-

e. Manfaat TambahanPenggantian biaya P3K Rp. 1.000.000,- dan Manfaat Biaya tambahan Penggantian biaya Ambulance Rp.500.000,-

\section{KESIMPULAN}

Tanggung jawab ganti kerugian pada korban kecelakaan Peumpang Umum di jalan raya karena kesalahan Pihak Pengangkut dilakukan yang secara kekeluargaan, berdasarkan prinsip tanggung jawab adanya unsur kesalahan Pihak Pengangkut ini memberikan pelajaran bahwa tanggung jawab setiap orang terletak pada ada atau tidaknya kesalahan yang diperbuat. Tidak ada satupun seseorang yang bertanggung jawab tanpa adanya suatu kesalahan dari Pihak Perusahaan Pengangkutan. Menurut prinsip tanggung jawab berdasarkan praduga (presumption of liability) Pihak pengusaha angkutan dianggap selalu yang bertanggung jawab pada setiap kerugian yang timbul dari pengangkutan yang diselenggarakannya, tetapi jika pengangkut dapat membuktikan bawa ia tidak bersalah, maka ia dibebaskan dari kewajiban membayar ganti kerugian.

Pelaksanaan ganti kerugian, terhadap korban kecelakaan lalu lintas jalan oleh PT. (Pesero) Asuransi kerugian Jasa Raharja yaitu dengan :

a. Cara korban atau ahli waris datang ke kantor jasa raharja untuk meminta formulir K1 (untuk kecelakaan ditabrak kendaraan bermotor) atau K2 (untuk kecelakaan penumpang umum) diisi dengan benar.

b. Memenuhi syarat-syarat antara lain : keterangan kecelakaan lalu lintas jalan oleh kepolisian, keterangan dokter, serta keterangan ahli waris apabila korban meninggal dan apabila syaratsyarat tersebut telah terpenuhi dengan benar, maka proses pemberian ganti kerugian akan dapat berjalan dengan lancar.

\section{DAFTAR PUSTAKA}

Abdul Kadir Muhammad, Hukum Pengangkutan darat, Laut, Udara, Citra Aditya Bhakti, Bandung, 1999.

Abas Salam, A. Dasar-dasar Asuransi, Jakarta, Rajawali Press, 1991.

E. Saefullah Wiradipradja, Tanggungjawab Pengangkut Dalam Hukum Udara Internasional dan Nasional, Liberty, Yogyakarta, 1989.

E. Saefullah Wiradipradja, Penerapan Prinsip Tanggungjawab Mutlak (Strict Liability) Dalam Peraturan Perundang-undangan Khususnya di Bidang Angkutan Udara, Pidato Pengukuhan Guru Besar Tetap Ilmu Hukum, Fakultas Hukum Universitas Padjajaran, Bandung, Bandung, 1991.

Kaihatu JB. Asas-asas Asuransi, Jakarta, Djambatan, 1994.

Mehr, Cammark, Priciple of Insurance, disadur Drs. A. Hasym, Dasar-dasar Akuntansi, Pichar D. Irwin, Inc, Balai Aksara, Jakarta, 7 Mei 1993.

Purwosutjipto, SH, Pengertian PokokPokok Hukum Dagang di Indonesia, Jilid 6 (Hukum Pertanggungan) Jakarta, Djambatan, 1993.

Pangaribuan Emny, Hukum Pertanggungan Pokok-Pokok Pertanggungan Kerugian, Kebakaran dan Jiwa, Seksi Hukum Dagang FH. UGM, Yogyakarta. 
Mig Irianto Legowo : Prinsip Tanggung Jawab Pengangkut dan Asuransi Ganti Rugi .....

Projodikoro, Wiyono, Hukum Asuransi di Indonesia, Jilid 6 (Hukum Pertanggungan).

Subekti R. Tjitrosudibio, KUH Perdata, PT. Pradnya Paramita, Jakarta.

Rustian Kamaluddin, Ekonomi Transportasi, Karakteristik, Teori Dan Kebijakan, Ghalia Indonesia, Jakarta, 2003.

Sri Rejeki Hartono, Pengangkutan dan Hukum pengangkutan Darat, Seksi Hukum Dagang, Fakultas Hukum Universitas Diponegoro, Semarang, 1982.

Soerjocaroko, Samiadji, Pokok-pokok Hukum Pertanggungan Ganti Kerugian, Semarang, BPHKUNDIP, 1994.

Undang-undang nomor 22 tahun 2009 Tentang Lalu-lintas dan angkutan jalan.
Undang-undang No.33 Tahun 1964 tentang Dana Pertanggungan Wajib Kecelakaan Penumpang Umum.

Undang-undang No.34 Tahun 1964 tentang Dana Pertanggungan wajib Kecelakaan lalu Lintas Jalan.

Bagian Klaim, PT. (Pesero) Asuransi kerugian Jasa Raharja Cabang Kota Semarang .

Kasubbag Pelayanan Masyarakat PT. (Pesero) Asuransi Kerugian Jasa Raharja Cabang Kota Semarang.

Dalam Per mhtmi:File://D:|Dok.Untag $\backslash$ Cara Klaim Asuransi Kecelakaan Jasa Raharja, mht! http://Pemuda Indonesia Baru, 9-8-2011 